\title{
Extension of a coronary intramural hematoma after blunt chest trauma
}

\author{
Maeng Real Park, M.D., Mun Ki Min, M.D., Ji Ho Ryu, M.D., Dae Sub Lee, M.D., Kang Ho Lee, M.D.
}

Department of Emergency Medicine, Pusan National University Yangsan Hospital, Korea Yangsan-South Korea

\begin{abstract}
Coronary artery dissection and intramural hematoma after blunt chest trauma are rare, but life-threatening, complications. Coronary intramural hematoma extension is even rarer. A 31 -year-old man was transferred to our hospital for worsening left chest pain during while he was admitted at a nearby hospital due to blunt chest trauma. Bedside echocardiography showed akinesis of the left ventricular apex and anterior wall as well as hypokinesis of the mid-to-basal anteroseptal wall and mid-to-basal lateral and posterior walls of the left ventricle. Computed tomography coronary angiography revealed intramural hematoma in the left main (LM) coronary and proximal left anterior descending (LAD) arteries. Percutaneous coronary intervention, with bare metal stent implantation from the LM coronary artery to the proximal LAD artery, was performed to treat the occlusion caused by the hematoma. After stenting, the hematoma that compressed the LM coronary artery shifted the left circumflex (LCX) artery, and the intramural hematoma developed and extended to the LCX artery. To resolve this occlusion, a drug-eluting stent was successfully implanted in the LCX artery. The patient was discharged without complications. At 2-month follow-up, he remained asymptomatic, with no recurrence of cardiovascular symptoms. Delayed chest pain after trauma should be suspected during coronary dissection, and on treatment, care must be taken to extend the hematoma.
\end{abstract}

Keywords: Chest trauma; coronary artery dissection; coronary intramural hematoma.

\section{INTRODUCTION}

Coronary artery dissection and intramural hematoma after blunt chest trauma are rare, but life-threatening, complications. ${ }^{[-4]}$ Coronary intramural hematoma extension is even rarer. These injures may cause an acute myocardial infarction, and patients may report angina-like pain. We report a case of development and extension of an intramural hematoma toward the left circumflex (LCX) artery during percutaneous coronary intervention $(\mathrm{PCl})$ to treat intramural hematoma in the left main (LM) coronary and proximal left anterior descending (LAD) arteries after blunt chest trauma.

\section{CASE REPORT}

A 31 -year-old man, with no medical history, was transferred to our hospital for worsening left chest pain. He had been admitted at a nearby hospital due to trauma following a motorcycle accident 10 days before admission to our hospital. No fractures or internal organ injuries were found on initial examinations [chest computed tomography (CT), brain CT, Xray, laboratory examination] performed at the first hospital.

At the time of transfer, his vital signs were as follows: blood pressure, 120/78 mmHg; pulse rate, 72 beats/min; respiratory rate, 20 breaths/min; and saturation, 99\%. A 12-lead ECG showed ST depression in lead I, lead II, aVF, V2, V3, V4, V5, and V6, and ST elevation in aVR (Fig. I). Bedside echocardiography showed akinesis of the left ventricular apex and anterior wall as well as hypokinesis of the mid-to-basal anteroseptal wall and mid-to-basal lateral and posterior walls

Cite this article as: Park MR, Min MK, Ryu JH, Lee DS, Lee KH. Extension of a coronary intramural hematoma after blunt chest trauma. Ulus Travma Acil Cerrahi Derg 2018;24:78-81

Address for correspondence: Mun Ki Min, M.D.

Geumo-ro 20, Mulgeum-eup, Yangsan, Gyeongnam, 626-770, Korea Yangsan-South Korea.

Tel: 082-55-360-I467 E-mail: broadman@hanmail.net

Ulus Travma Acil Cerrahi Derg 2018;24(I):78-8I DOI: 10.5505/tjtes.2017.72393 Submitted: 25.05 .2017 Accepted: 10.1I.2017

Copyright 2018 Turkish Association of Trauma and Emergency Surgery 


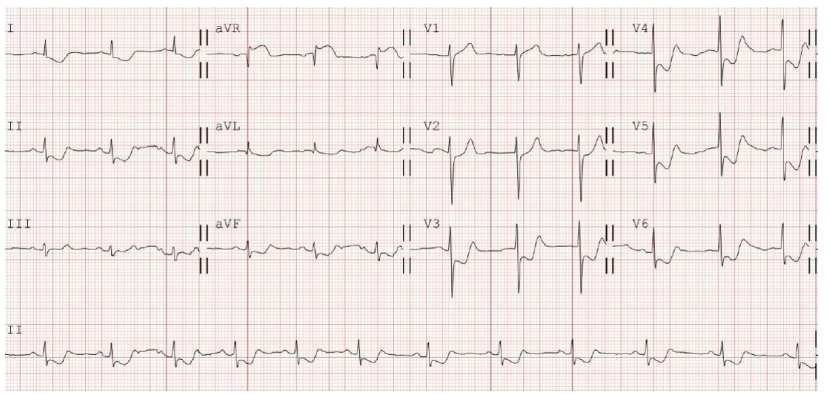

Figure 1. Electrocardiogram shows ST depression in lead I, lead II, aVF, V2, V3, V4, V5, and V6, and ST elevation in aVR.

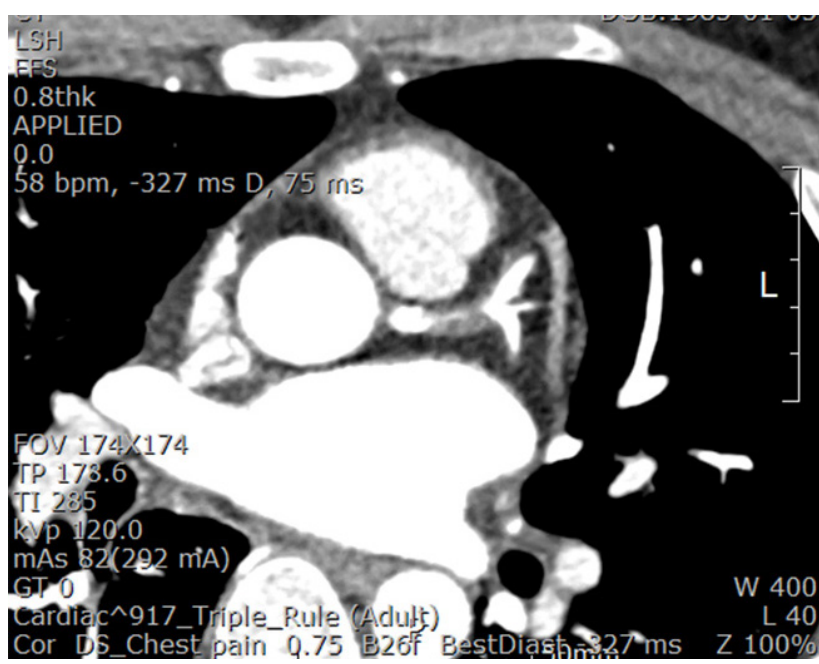

Figure 2. Computed tomography angiography revealed an intramural hematoma from the left main coronary artery to the left anterior descending artery. of the left ventricle, with preserved left ventricular ejection fraction of $56 \%$. Serum levels of troponin I, creatine kinase, and $\mathrm{MB}$ isoenzymes were $0.24 \mathrm{ng} / \mathrm{ml}, 337 \mathrm{U} / \mathrm{L}$, and $7.6 \mathrm{ng} / \mathrm{ml}$, respectively. CT coronary angiography revealed intramural hematoma in the LM coronary and proximal LAD arteries. There was no evidence of aortic dissection or pulmonary thromboembolism (Fig. 2). Urgent coronary angiography revealed nearly total occlusion of the LM coronary artery, with a thrombolysis in myocardial infarction distal flow score of 2 due to intramural hematoma. $\mathrm{PCl}$ with bare metal stent (Liberte $4.5 \times 20 \mathrm{~mm}$ ) implantation from the LM coronary artery to the proximal LAD artery was performed (Fig. $3 a-c$ ) to treat the occlusion caused by hematoma. After stenting, the hematoma compressing the LM coronary artery shifted the LCX artery, and the intramural hematoma developed and extended to the LCX artery. This intramural hematoma was diagnosed by intravascular ultrasound (IVUS). To resolve this occlusion, a drug-eluting stent (Synergy $4.0 \times 16 \mathrm{~mm}$ ) was successfully implanted in the LCX artery (Fig. $3 d-f$ ). The patient was discharged without complications. At 2-month follow-up, he remained asymptomatic, with no recurrence of cardiovascular symptoms.

\section{DISCUSSION}

Cardiac injuries after blunt chest trauma are common (5\%15\%). ${ }^{[5]}$ Autopsy studies have revealed that the incidence of coronary artery injuries secondary to blunt chest trauma is approximately $2 \%{ }^{[6]}$ Coronary artery injuries resulting in myocardial infarction and ischemia are extremely rare after blunt chest trauma. ${ }^{[7-9]}$ The LAD artery is the most commonly af-
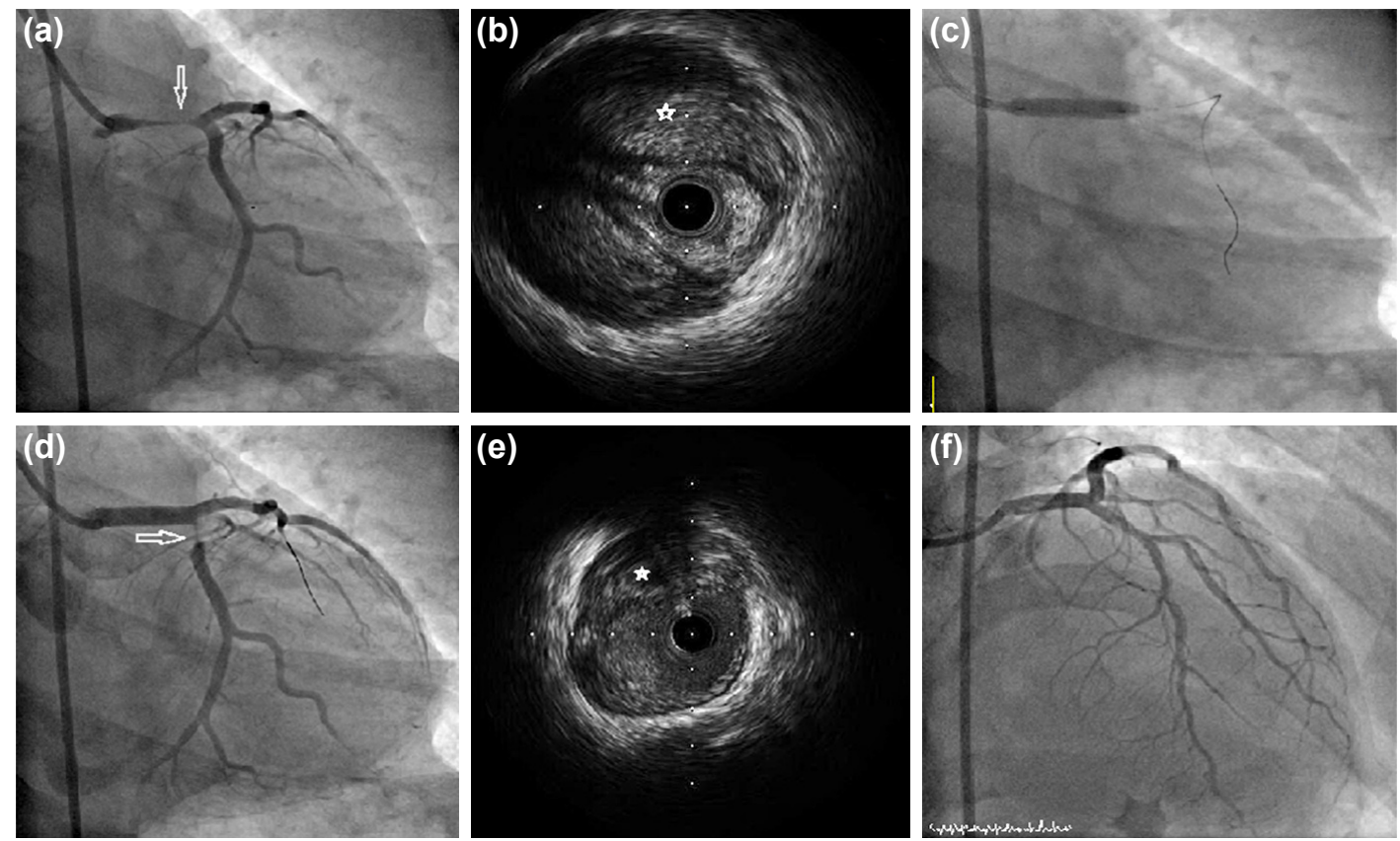

Figure 3. (a) The left main coronary and left anterior descending arteries compressed by the intramural hematoma; (b) Intravascular ultrasound (IVUS) confirmation of the diagnosis; (c) Stenting; (d, e) After stenting, the hematoma shifted the left circumflex (LCX) artery, and (f) the intramural hematoma developed and extended to the LCX artery. The hematoma was confirmed by IVUS. White arrow indicates artery that the intramural hematoma compressed. White asterisk indicates the hematoma identified by IVUS. 
fected vessel (7I.4\%), followed by the right coronary (19\%), LM coronary $(6.4 \%)$, and LCX (3.2\%) arteries. ${ }^{[10]}$

Significant delays (up to seven days) between blunt chest trauma and coronary artery dissection have been reported. [1] High awareness of intramural hematomas or dissections is required when performing $\mathrm{PCl}$, because a hematoma may appear as diffuse coronary luminal narrowing.

In the present case, the patient reported chest pain seven days after trauma, and CT angiography revealed a coronary intramural hematoma. Hypokinesis and akinesis shown by echocardiography indicated cardiac ischemia or infarction.

This was a case of an intramural hematoma in the LM coronary and LAD arteries after blunt chest trauma and extension of the hematoma to the LCX artery. The hematoma was successfully detected by IVUS and treated with multiple stents. A few cases of coronary artery dissection and extension of an intramural hematoma after $\mathrm{PCl}$ have been reported; $\left[{ }^{[1,13]}\right.$ however, to our knowledge, this is the first case of extension of an intramural hematoma after blunt chest trauma.

Although the mechanism and cause of the extension of an intramural hematoma are not known, vessels facilitating the extension of a hematoma are typically relatively healthy, thereby allowing propagation of blood within the media, without being impeded by calcific or fibrotic plaque. ${ }^{[14]} A$ previous study reported that previous thrombolytic therapy affected hematoma extension after $\mathrm{PCl}^{\left[{ }^{[12]}\right.}$ In the present case, it was thought that microvascular damage of the blood vessels might have affected the hematoma.

Although there is no clear consensus regarding the management of a multivessel intramural hematoma, the key principal of re-establishing coronary flow in the setting of ongoing ischemia, as with any acute coronary syndrome, still applies. ${ }^{[15]}$

\section{Conclusion}

Coronary artery dissection and intramural hematoma after blunt chest trauma are rare, but life-threatening, complications. Coronary intramural hematoma extension is even rarer. Delayed chest pain after trauma should be suspected during coronary dissection, and on $\mathrm{PCl}$, care must be taken to extent the hematoma.

Conflict of interest: None declared.

\section{REFERENCES}

1. Colombo F, Zuffi A, Lupi A. Left main dissection complicating blunt chest trauma: case report and review of literature. Cardiovasc Revasc Med 2014;15:354-6. [CrossRef]

2. da Silva AC, de Paula JE, Mozer GW, Toledo LF, Soares RL, Albertal M. Simultaneous dissection and intramural hematoma of left anterior descending and circumflex coronary arteries after blunt chest trauma. Int J Cardiol 2012;155:e34-6. [CrossRef]

3. Voyce SJ, Ball SP, Gore JM, Shine WJ, Weiner BH. Angiographically documented thrombotic coronary artery occlusion secondary to mild nonpenetrating thoracic trauma. Cathet Cardiovasc Diagn 1991;24:179-81.

4. Kohli S, Saperia GM, Waksmonski CA, Pezzella S, Singh JB. Coronary artery dissection secondary to blunt chest trauma. Cathet Cardiovasc Diagn 1988;15:179-83. [CrossRef]

5. Atalar E, Açil T, Aytemir K, Ozer N, Ovünç K, Aksöyek S, et al. Acute anterior myocardial infarction following a mild nonpenetrating chest trauma-a case report. Angiology 2001;52:279-82. [CrossRef]

6. Prêtre R, Chilcott M. Blunt trauma to the heart and great vessels. N Engl J Med 1997;336:626-32. [CrossRef]

7. Wilczynska-Golonka M, Rostoff P, Siniarski A, Skrzypek A, Gackowski A, Konduracka E, et al. Trauma-induced acute myocardial infarction due to delayed dissection of the left anterior descending coronary artery. Am J Emerg Med 2017;35:939.e1-2. [CrossRef]

8. Zeng C, Hu W, Zhu N, Zhao X, Xu J, Ye S, et al. Right coronary artery dissection and aneurysm presented as acute inferior myocardial infarction from an automobile airbag trauma. Am J Emerg Med 2015;33:1537. e5-7.

9. Sasaki T, Temmoku J, Inukai T, Sugiyama T, Inokuchi R, Shinohara K. Acute myocardial infarction after trauma: potency of percutaneous coronary intervention with transcatheter arterial embolization. Am J Emerg Med 2016;34:1186.e1-3. [CrossRef]

10. Christensen MD, Nielsen PE, Sleight P. Prior blunt chest trauma may be a cause of single vessel coronary disease; hypothesis and review. Int J Cardiol 2006;108:1-5. [CrossRef]

11. Poyet R, Capilla E, Kerebel S, Brocq FX, Pons F, Jego C, et al. Acute myocardial infarction and coronary artery dissection following rugby-related blunt chest trauma in France. J Emerg Trauma Shock 2015;8:110-1.

12. El-Mawardy M, Abdel-Wahab M, Richardt G. Extension of a coronary intramural hematoma as a complication of early percutaneous coronary intervention after thrombolytic therapy. Case Rep Med 2013;2013:218389. [CrossRef]

13. Hirose M, Kobayashi Y, Kreps EM, Stone GW, Moussa I, Leon MB, et al. Luminal narrowing due to intramural hematoma shift from left anterior descending coronary artery to left circumflex artery. Catheter Cardiovasc Interv 2004;62:461-5. [CrossRef]

14. Maehara A, Mintz GS, Bui AB, Castagna MT, Walter OR, Pappas C, et al. Incidence, morphology, angiographic findings, and outcomes of intramural hematomas after percutaneous coronary interventions: an intravascular ultrasound study. Circulation 2002;105:2037-42. [CrossRef]

15. Haden G, Polenta S, Jelnin V, Soffer D, Hecht H. Images in cardiology: postpartum intramural hematoma-evaluation by computed tomographic angiography. J Clin Hypertens (Greenwich) 2009;11:656. [CrossRef] 


\section{OLGU SUNUMU - ÖZET}

\section{Künt göğüs travması sonrası koroner intramüral hematomun yayılması \\ Dr. Maeng Real Park, Dr. Mun Ki Min, Dr. Ji Ho Ryu, Dr. Dae Sub Lee, Dr. Kang Ho Lee}

Pusan Ulusal Üniversitesi, Yangsan Hastanesi, Acil Tıp Kliniği, Yangsan, Güney Kore

Künt göğüs travması sonrası koroner arter diseksiyonu ve intramüral hematom seyrek görülen, ancak yaşamı tehdit edici bir komplikasyondur. Koroner intramüral hematomun yayılması ise çok daha seyrek görülür. Otuz bir yaşındaki erkek yakındaki bir hastaneye künt göğüs travması nedeniyle kabulü sırasında kötüleşen sol göğüs ağrısı nedeniyle hastanemize sevk edildi. Hasta başı ekokardiyografısinde sol ventriküler apeks ve ön duvarda akinezi, sol ventrikül anteroseptal duvar ve arka duvarlarının orta-alt bölümlerinde hipokinezi görüldü. Bilgisayarlı tomografı koroner anjiyografi sol ana koroner arter ve proksimal sol ön inen arterde intramüral hematomun varlığını gösterdi. Hematomun neden olduğu tıkanıklığı açmak için sol ana koroner arterden proksimal sol sirkumfleks (LCX) artere perkütan koroner girişim (PKG) ile çıplak metal stent implante edildi. Stentlemeden sonra sol ana koroner arteri baskılayan hematom LCX artere doğru yer değiştirdi. Yine intramüral hematom gelişti ve LCX'e uzandı. Bu tıkanıklığı çözmek için bir ilaç salan stent başarıyla LCX arter içine implante edildi. Hasta komplikasyonsuz taburcu edildi. İzlemin ikinci ayında hasta semptomsuzdu ve hastada kardiyovasküler semptomlar nüksetmemişti. Travma sonrası geç dönemde oluşan göğüs ağrısı koroner arter diseksiyonundan kuşkulandırmalı ve hematomun genişlemesine karşı dikkatli olunmalıdır.

Anahtar sözcükler: Gögüs travması; intramüral hematom; koroner arter diseksiyonu.

Ulus Travma Acil Cerrahi Derg 2018;24(I):78-8I doi: 10.5505/tjtes.2017.72393 